\title{
Thermal denaturation of whole cells and cell components of Escherichia coli examined by differential scanning calorimetry
}

\author{
B. M. Mackey,${ }^{*} \dagger$ C. A. Miles, $\ddagger$ S. E. Parsons and D. A. Seymour \\ AFRC Institute of Food Research, Bristol Laboratory, Langford, Bristol BS18 7DY, UK
}

(Received 15 January 1991; revised 23 May 1991; accepted 2 July 1991)

\begin{abstract}
Thermograms of whole cells of Escherichia coli obtained by differential scanning calorimetry contained ten main peaks (denoted $f, l, m_{1}, m_{2}, m_{3}, n, p, q, r$ and $s$ ) occurring at temperatures of approximately $25,54,61,71,76,81$, $95,105,118$ and $124^{\circ} \mathrm{C}$, respectively. After cooling to $5{ }^{\circ} \mathrm{C}$ and reheating, peaks denoted $f_{\mathrm{r}}, m_{\mathrm{r}}$ and $p_{\mathrm{r}}$ were observed at 23,73 and $94^{\circ} \mathrm{C}$, respectively. By examining thermograms of different cell fractions we have identified the following thermal denaturation events. During primary heating there is a broad endotherm $(f)$ beginning below $20{ }^{\circ} \mathrm{C}$ and extending to just above $40^{\circ} \mathrm{C}$ that is caused by melting of membrane lipids. Superimposed on this is an exothermic process associated with a change of state of the peptidoglycan. The first irreversible denaturation event occurs just above $47^{\circ} \mathrm{C}$, associated with the onset of denaturation of the $30 \mathrm{~S}$ ribosomal subunit and soluble cytoplasmic proteins. Ribosome melting is a complex process occurring between 47 and $85{ }^{\circ} \mathrm{C}$ and is characterized by peaks $m_{1}, m_{2}$ and $n$. Peak $m_{3}$ at $75-76{ }^{\circ} \mathrm{C}$ is of unknown identity but may possibly represent melting of tRNA. Peak $p$ at $95{ }^{\circ} \mathrm{C}$ results from melting of a portion of the cellular DNA combined with denaturation of a cell wall component. Peak $q$ at $105^{\circ} \mathrm{C}$ is multicomponent and may be caused by melting of a different region of DNA together with denaturation of another cell wall component. The complex events denoted $r$ and $s$ at 118 and $125^{\circ} \mathrm{C}$, respectively, are associated with denaturation of a component of the cell envelope, and possibly also of DNA. Following cooling and reheating there is a broad endotherm with a maximum at $23{ }^{\circ} \mathrm{C}$ caused by remelting of membrane lipid and a very broad endotherm extending between 40 and $100{ }^{\circ} \mathrm{C}$ caused by the remelting of ribosomal RNA. Peak $p_{\mathrm{r}}$ at $94^{\circ} \mathrm{C}$ is caused by the melting of reannealed DNA. Additional features not appearing in whole cells were evident in some cell fractions. These observations should allow us to distinguish events that may lead to loss of viability from those that do not.
\end{abstract}

\section{Introduction}

The inactivation of micro-organisms by heat forms the basis of large sections of the food and pharmaceutical industries. Not surprisingly, the factors affecting microbial heat-resistance and the nature of heat damage are of continuing practical and scientific concern.

The mechanisms of thermal inactivation of microorganisms have commonly been investigated by using biochemical methods to examine the effect of heat on particular cell structures or processes. Membranes, nucleic acids and certain enzymes have all been identified as cellular sites of heat injury and, in some cases, information is available on the molecular nature of heat damage (Tomlins \& Ordal, 1976; Pellon \& Sinskey,

$\dagger$ Present address: AFRC Institute of Food Research, Reading Laboratory, Shinfield, Reading RG2 9AT, UK.

$\ddagger$ Present address: University of Bristol, Churchill Building, Langford, Bristol, UK.
1984; Gould, 1989). However, despite this large body of information, we still do not understand precisely how micro-organisms are killed by heat.

Differential scanning calorimetry (DSC) enables denaturation and other thermal processes that occur when samples are heated to be detected and recorded as a time-temperature sequence. The technique has been used to study thermotropic phase changes in membrane lipids (McElhaney, 1982, 1986), activation and germination of spores (Maeda et al., 1974; Verbeke et al., 1981), and the state of water in bacterial cells (Gonda \& Koga, 1973).

Verrips \& Kwast (1977) examined vegetative cells of Citrobacter freundii by DSC and obtained thermograms consisting of eight unidentified endothermic peaks. Two peaks, at 50 and $55^{\circ} \mathrm{C}$, coincided with the temperature over which death was thought to occur but the relationship between temperature and the rate at which viable organisms declined in the calorimeter was not established. 
In previous work, we examined by DSC several species of bacteria having natural differences in heat resistance (Miles et al., 1986). Each species produced a characteristic multipeaked thermogram but the onset of thermal denaturation occurred at higher temperatures in the more resistant types than in those that were heat sensitive. Additionally, some heat-sensitive organisms displayed thermogram features which were absent in those more resistant. In all organisms the onset of irreversible denaturation occurred at or above the maximum growth temperature but below the temperature at which most cells in the population died (calculated from $D$ and $z$ values). Cell death and irreversible denaturation thus occurred within the same temperature range.

In order to relate loss of viability to the denaturation of particular cell components, we need to identify the various features observed in thermograms of whole cells. We have identified one substantially reversible process in Escherichia coli as the melting endotherm of DNA (Miles et al., 1986; Mackey et al., 1988) but the other peaks remain uncharacterized.

The aim of this work was to identify the major thermogram features that are observed when whole cells of $E$. coli are heated in the calorimeter. To do this we have fractionated the cell into its substituent components and compared the thermogram given by each fraction with that observed in whole cells.

\section{Methods}

Organisms and growth conditions. Escherichia coli NCTC 8164 lacking ribonuclease I was used in all cell fractionation experiments. E. coli DS410 (Dougan \& Sherratt, 1977) was used for obtaining minicells. Cells were grown at $37^{\circ} \mathrm{C}$ in tryptone soya broth (Oxoid) supplemented with $3.0 \mathrm{~g}$ yeast extract $\mathrm{l}^{-1}$. For volumes of up to $3 \mathrm{l}$, growth was in one or more conical flasks contained in a shaking water bath; for the larger volumes required in ribosome or minicell preparation, growth was in a 101 fermenter aerated by sparging. Cultures for cell fractionation were grown to an $\mathrm{OD}_{680}$ of 1.0 ; those used for minicell preparation were grown for $18 \mathrm{~h}$. Cells were chilled on ice and harvested by centrifugation at $10000 \mathrm{~g}$ for $5 \mathrm{~min}$

Sequential fractionation. Cell pellets from 31 of culture were washed once and resuspended in 1.5 pellet volumes of a buffer containing $200 \mathrm{~mm}$-potassium glutamate, $10 \mathrm{mM}$-sodium hydrogen phosphate and 5 mM-magnesium chloride, $\mathrm{pH} 7.8$. The ionic composition of this buffer was intended to approximate that existing within whole cells. The concentrated cell suspension was placed in an X-press (Life Science Laboratories) previously cooled to $-25^{\circ} \mathrm{C}$. After holding for $20 \mathrm{~min}$, the frozen cells were disrupted by passing once or twice through the pressure cell. After thawing, the viscous paste of broken cells was stored on ice. Deoxyribonuclease (DNAase) (Sigma, $0.2 \mathrm{mg} \mathrm{ml}^{-1}$ ) was added and the material centrifuged at $32500 \mathrm{~g}$ for $30 \mathrm{~min}$. The pellet of whole and broken cells was saved to prepare a crude cell envelope fraction (see below). The supernatant liquid (cell-free extract) was centrifuged at $150000 \mathrm{~g}$ for $3.5 \mathrm{~h}$ to give a pellet of crude ribosomes. The ribosome-free supernatant liquid was retained and, in some cases, concentrated up to sevenfold by dialysis in a Minicon B-15 concentrator (Amicon). To examine the ribosome content of the cellfree and ribosome-free extracts, the fractions were diluted 1000 -fold in glutamate buffer and $3 \mathrm{ml}$ of this suspension was applied to $15 \mathrm{ml}$ of a $10-30 \%(w / v)$ linear sucrose gradient in glutamate buffer. The gradients were centrifuged at $90000 \mathrm{~g}$ for $2.5 \mathrm{~h}$ then pumped out by upward displacement with $\mathbf{4 0} \%$ sucrose. Fractions were monitored by measuring $\boldsymbol{A}_{\mathbf{2 6 0}}$. Samples of the following were retained for chemical analysis and examination by differential scanning calorimetry: washed whole cells; broken cells before addition of DNAase; cell-free extract; crude ribosomes; ribosome-free extract; cell envelopes.

Preparation of cell envelopes. The pellet of whole and broken cells from the cell fractionation was resuspended in glutamate buffer and then spun at $8000 \mathrm{~g}$ for $10 \mathrm{~min}$ to remove whole cells. The cell envelopes were then pelleted by centrifugation at $100000 \mathrm{~g}$ for $1.25 \mathrm{~h}$ and washed twice in buffer. Alternatively, cell envelopes were prepared by two or three cycles of low-speed $(4000 \mathrm{~g})$ and high-speed $(30000 \mathrm{~g})$ centrifugation.

Preparation of peptidoglycan. Peptidoglycan was prepared as described by Hancock \& Poxton (1988). Cells from a 21 culture were washed once in water and resuspended in $50 \mathrm{ml}$ water. The suspension was kept on ice and added dropwise to $50 \mathrm{ml}$ boiling $8 \%$ (w/v) SDS, then boiled for a further $20 \mathrm{~min}$. After cooling overnight at room temperature, the SDS-insoluble material was spun down at $100000 \mathrm{~g}$ for $1 \mathrm{~h}$. The pellet was washed four times with water, twice with $2 \mathrm{M}$ $\mathrm{NaCl}$, then four times with water. The pellet was finally washed once in glutamate buffer.

Lipid extraction. Cells from 11 of culture were harvested by centrifugation and washed twice in $10 \mathrm{~mm}-\mathrm{Tris} / \mathrm{HCl}, \mathrm{pH} 7.5$, containing $10 \mathrm{mM}-\mathrm{MgCl}_{2}$. The cell pellet was finally resuspended in $4 \mathrm{ml}$ buffer and placed in a stoppered tube with $10 \mathrm{ml}$ methanol and $5 \mathrm{ml}$ chloroform. The mixture was shaken vigorously, kept on ice for $10 \mathrm{~min}$ and then $4 \mathrm{ml}$ chloroform was added followed by $4 \mathrm{ml}$ water. After mixing, the suspension was spun in a bench centrifuge to separate the layers. The lower chloroform layer was removed and the chloroform evaporated off using a stream of oxygen-free nitrogen. The resulting lipid was redissolved in a small volume of chloroform and stored at $-20^{\circ} \mathrm{C}$ under oxygen-free nitrogen.

Preparation of ribosomes and ribosomal subunits. The following buffers were used: basal buffer, containing $10 \mathrm{mM}-\mathrm{Tris} / \mathrm{HCl}, 10 \mathrm{mM}-\mathrm{MgCl}_{2}$,

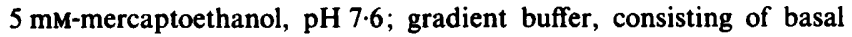
buffer plus $1 \mathrm{M}-\mathrm{NH}_{4} \mathrm{Cl}$ and $20 \%(\mathrm{w} / \mathrm{v})$ sucrose; storage buffer, consisting of basal buffer plus $50 \mathrm{mM}-\mathrm{NH}_{4} \mathrm{Cl}$; subunit buffer, containing $20 \mathrm{~mm}-\mathrm{T}$ ris $/ \mathrm{HCl}, 1 \mathrm{~mm}-\mathrm{MgCl}_{2}, 150 \mathrm{~mm}-\mathrm{NH}_{4} \mathrm{Cl}, 5 \mathrm{~mm}-$ mercaptoethanol, $\mathrm{pH}$ 7.6. To prepare ribosomes, the cell pellet from a 101 culture was washed once in basal buffer and then resuspended in the same buffer with $0.2 \mathrm{mg} \mathrm{DNAase} \mathrm{ml}^{-1}$. The cells were disrupted by passage through the $\mathrm{X}$-press, as described above, and broken cells were removed by centrifugation at $10000 \mathrm{~g}$ for $5 \mathrm{~min}$. The supernatant was centrifuged at $26500 \mathrm{~g}$ for $30 \mathrm{~min}$ to remove cell debris, then layered onto 2 vols gradient buffer and spun at $140000 \mathrm{~g}$ for $6 \mathrm{~h}$. This yielded a clear glassy pellet of ribosomes which was resuspended to a volume of $10 \mathrm{ml}$ in storage buffer, dispensed into plastic tubes and stored at $-70^{\circ} \mathrm{C}$

For preparation of subunits, aliquots of ribosomes in storage buffer were thawed and spun down at $100000 \mathrm{~g}$ for $3 \mathrm{~h}$. The pellet was thoroughly homogenized with subunit buffer and recentrifuged. The pellet was once again homogenized with subunit buffer $(5 \mathrm{ml})$ and dialysed for $24 \mathrm{~h}$ at $1{ }^{\circ} \mathrm{C}$ against two changes of $200 \mathrm{ml}$ of the same buffer. The dialysate was then layered onto $54 \mathrm{ml}$ of a $10-30 \%$ sucrose gradient in subunit buffer. The gradient was spun at $35000 \mathrm{~g}$ for $16 \mathrm{~h}$ at $4{ }^{\circ} \mathrm{C}$ and pumped out by upwards displacement using $40 \%$ sucrose. 
Fractions ( $1 \mathrm{ml}$ ) were collected, and their $A_{260}$ measured. Peak fractions were pooled, diluted with subunit buffer and centrifuged at $140000 \mathrm{~g}$ for $19 \mathrm{~h}$. The pellets were resuspended in $5 \mathrm{ml}$ subunit buffer and rerun on two separate $10-30 \%$ sucrose gradients as before. Again, the gradients were pumped out and $1 \mathrm{ml}$ fractions collected. The peak fractions were pooled, diluted with subunit buffer and centrifuged at $140000 \mathrm{~g}$ for $24 \mathrm{~h}$. The pellets were thoroughly homogenized, washed twice in glutamate buffer and collected by centrifugation at $140000 \mathrm{~g}$ for $19 \mathrm{~h}$.

Preparation of minicells. Ten litres of culture was chilled by pumping into flasks surrounded by ice-water, then concentrated to $800 \mathrm{ml}$ by tangential-flow filtration (Millipore). The concentrated suspension was centrifuged at $1000 \mathrm{~g}$ for $5 \mathrm{~min}$ to remove most of the whole cells. Minicells and remaining whole cells were sedimented by centrifugation at $15000 \mathrm{~g}$ for $15 \mathrm{~min}$. Pellets were resuspended to $15 \mathrm{ml}$ with $\mathrm{M9}$ medium (Miller, 1972) and $5 \mathrm{ml}$ portions layered onto $54 \mathrm{ml}$ volumes of $10-30 \%$ sucrose gradients in $\mathrm{M} 9$ medium. The gradients were spun at $5000 \mathrm{~g}$ for $5 \mathrm{~min}$ to separate minicells and whole cells and the top twothirds of the (upper) minicell band removed. The minicell fractions were pooled, diluted with an equal volume of M9 medium and pelleted by centrifugation at $22000 \mathrm{~g}$ for $10 \mathrm{~min}$. The pellet was resuspended to $5 \mathrm{ml}$ with $\mathrm{M} 9$ medium then purified by another gradient run as above. The final pellet of minicells was washed twice in glutamate buffer, then examined by DSC.

Nucleic acids. Solutions of DNA, rRNA and tRNA from $E$. coli were obtained from Sigma and diluted to $10 \mathrm{mg} \mathrm{ml}^{-1}$ in glutamate buffer.

Biochemical assays. All the cell fractions sampled for DSC were subsequently freeze-dried. Protein was assayed by the method of Lowry; RNA was assayed using orcinol reagent and DNA was assayed using diphenylamine reagent by the method of Burton, all as detailed by Herbert et al. (1971).

Calorimetry. The calorimeter used was a Perkin-Elmer DSC-2C fitted with an Intracooler II, to allow temperature control below $30^{\circ} \mathrm{C}$. The dry box and DSC head were purged with oxygen-free nitrogen supplied via an in-line silica gel drier. Samples up to $20 \mathrm{mg}$ were weighed to $\pm 0.01 \mathrm{mg}$, sealed in aluminium pans and heated at $10^{\circ} \mathrm{C}$ $\min ^{-1}$ from 5 to $130^{\circ} \mathrm{C}$, using an empty pan as the reference. Without adjustment of the DSC or disturbance of the pans, the samples were cooled rapidly (arbitrarily $\left.320^{\circ} \mathrm{C} \mathrm{min}-1\right)$ to the lower limit $\left(5^{\circ} \mathrm{C}\right)$ then reheated as before. Data for the run and rerun were collected and the calorimeter was controlled by a Perkin-Elmer 3600 Data Station. The thermogram scans were than transferred to a VAX 11/750 computer for high-resolution plotting, determining peak temperatures and enthalpy measurements. Only those peaks that were consistently present in repeated scans were selected for analysis. Initial transients and some initial step-like features, that appeared to be instrumental artefacts, were ignored. Temperature and power scales were calibrated according to the manufacturer's instructions using indium and ice as standards. The sample dry mass was determined by reweighing the sample, after piercing the pan and drying overnight at $105 \pm 1{ }^{\circ} \mathrm{C}$.

\section{Results}

\section{Cell fractionation studies}

In the first part of the investigation the bacterial cell was separated into its main constituent parts, with the aim of identifying the major thermogram features seen in whole cells. A simple, and therefore somewhat crude, protocol was used to minimize the number of manipulations
Table 1. Chemical composition of whole cells and fractions of whole cells of E. coli NCTC 8164

The results presented are from the sequential fractionation of a single batch of cells as described in Methods. The quoted values are the means $( \pm S D)$ of two samples, each assayed in duplicate. The values for dry matter content were obtained by drying the DSC samples and are the means of three samples.

\begin{tabular}{|c|c|c|c|c|c|}
\hline \multirow[b]{2}{*}{ Sample } & \multirow{2}{*}{$\begin{array}{l}\text { Dry matter } \\
\text { content } \\
\text { ( } \% \text { by mass) }\end{array}$} & \multicolumn{3}{|c|}{$\begin{array}{l}\text { Composition as a } \\
\text { percentage of } \\
\text { dry matter }\end{array}$} & \multirow{2}{*}{$\begin{array}{l}\text { Percentage } \\
\text { of total } \\
\text { dry matter } \\
\text { accounted fo }\end{array}$} \\
\hline & & Protein & DNA & RNA & \\
\hline Whole cells & $\begin{array}{c}24 \\
\pm 0 \cdot 4\end{array}$ & $\begin{array}{c}58 \\
+1.0\end{array}$ & $\begin{array}{r}1.9 \\
+0.10\end{array}$ & $\begin{array}{c}25 \\
+1.8\end{array}$ & 85 \\
\hline Broken cells & $\begin{array}{c}19 \\
+0.4\end{array}$ & $\begin{array}{c}54 \\
\pm 1.4\end{array}$ & $\begin{array}{r}1.9 \\
+0.07\end{array}$ & $\begin{array}{c}24 \\
\pm 3 \cdot 1\end{array}$ & 79 \\
\hline Cell-free extract & $\begin{array}{c}16 \\
\pm 0 \cdot 1\end{array}$ & $\begin{array}{c}54 \\
\pm 0.6\end{array}$ & $\begin{array}{c}0.4 \\
\pm 0.11\end{array}$ & $\begin{array}{c}21 \\
\pm 1.4\end{array}$ & 75 \\
\hline Crude ribosomes & $\begin{array}{c}36 \\
\pm 0 \cdot 3\end{array}$ & $\begin{array}{c}56 \\
\pm 1.4\end{array}$ & $\begin{array}{c}0.3 \\
\pm 0.02\end{array}$ & $\begin{array}{c}38 \\
\pm 5.5\end{array}$ & 95 \\
\hline $\begin{array}{l}\text { Ribosome-free } \\
\text { extract } \\
\text { (concentrated) }\end{array}$ & $\begin{array}{l}11 \\
\pm 0 \cdot 1\end{array}$ & $\begin{array}{l}66 \\
\pm 7.9\end{array}$ & $\begin{array}{c}0.2 \\
\pm 0.04\end{array}$ & $\begin{array}{r}1.8 \\
\pm 3.6\end{array}$ & 68 \\
\hline Cell envelopes & $\begin{array}{c}24 \\
\pm 0 \cdot 3\end{array}$ & $\begin{array}{c}42 \\
\pm 1.0\end{array}$ & ND & $\begin{array}{c}18 \\
\pm 2 \cdot 4\end{array}$ & 60 \\
\hline
\end{tabular}

ND, Not detected.

involved, and to enable a complete set of subfractions to be obtained from the same sample of starting material in a reasonable time. Each fraction examined by DSC was analysed for dry matter, DNA, RNA and protein (Table 1). The thermal data are summarized in Table 2.

\section{Whole cells}

The composition of the whole cells, i.e. $58 \%$ protein, $25 \%$ RNA, $1.9 \%$ DNA and $15 \%$ remainder, was similar to that given by Neidhardt (1987). Whole cells exhibited a multipeaked thermogram, reproducibly containing the features identified by letter in Fig. 1(a). The labelling of peaks follows that of our previous publications (Miles $e t$ al., 1986; Mackey et al., 1988) but is expanded to include $l, m_{1}, m_{2}$ and $m_{3}$ in the region of the main peak (previously labelled $m$ ), $s$ in the high temperature region and $f$ in the lower. On rerunning the sample after heating to $130{ }^{\circ} \mathrm{C}$ and cooling to $5{ }^{\circ} \mathrm{C}$, three apparently reversible peaks were evident; $f_{\mathrm{r}}, m_{\mathrm{r}}$ and $p_{\mathrm{r}}$ and the level, i.e. the specific heat capacity of heat-denatured cells, was slightly higher than that of undenatured cells in the lowtemperature region. To allow comparison between different subfractions, the same notation has been used throughout. Occasionally other features were observed in the rerun: endotherms at temperatures in excess of $p_{\mathrm{r}}$ and indications of a small dip in the $m_{\mathrm{r}}$ endotherm (as in Fig. 1), but these features varied in size and position and were not reproducible. 
Table 2. Temperatures of onset of thermal denaturation $\left(T_{0}\right)$ and temperatures of peak maxima $\left(T_{\max }\right)$ in the thermograms of whole cells and fractions of whole cells of E. coli NCTC 8164

The fractionation procedures are described in Methods. The quoted $T_{\max }$ values are the means, maxima and minima of individual peaks each averaged over three different preparations replicated three times except for the dilute ribosomes and ribosome-free extract fractions (two preparations each replicated three times). All peaks were recorded, even when very small in size (e.g. $m_{1}, m_{2}, m_{3}$ in the ribosome-free extract). Two of the three cell wall preparations appeared to be contaminated with ribosomes and this will have affected the data for peaks $m_{1}$ to $n$. It was only in the contaminated specimens that $m_{\mathrm{r}}$ was observed. Some features were present in some but not all of the scans and the number $N$ indicates the frequency of occurrence. $f$ was sometimes obscured by initial transients on the first heating run. Peaks $p, q, r$ and $s$ appeared to be multi-event processes in whole cells because they did not exhibit simple shapes with one obvious $T_{\max }$. In some fractions only a single component of these peaks was apparent; for example, the cell walls gave a sharp peak at $q_{1}$ peak only.

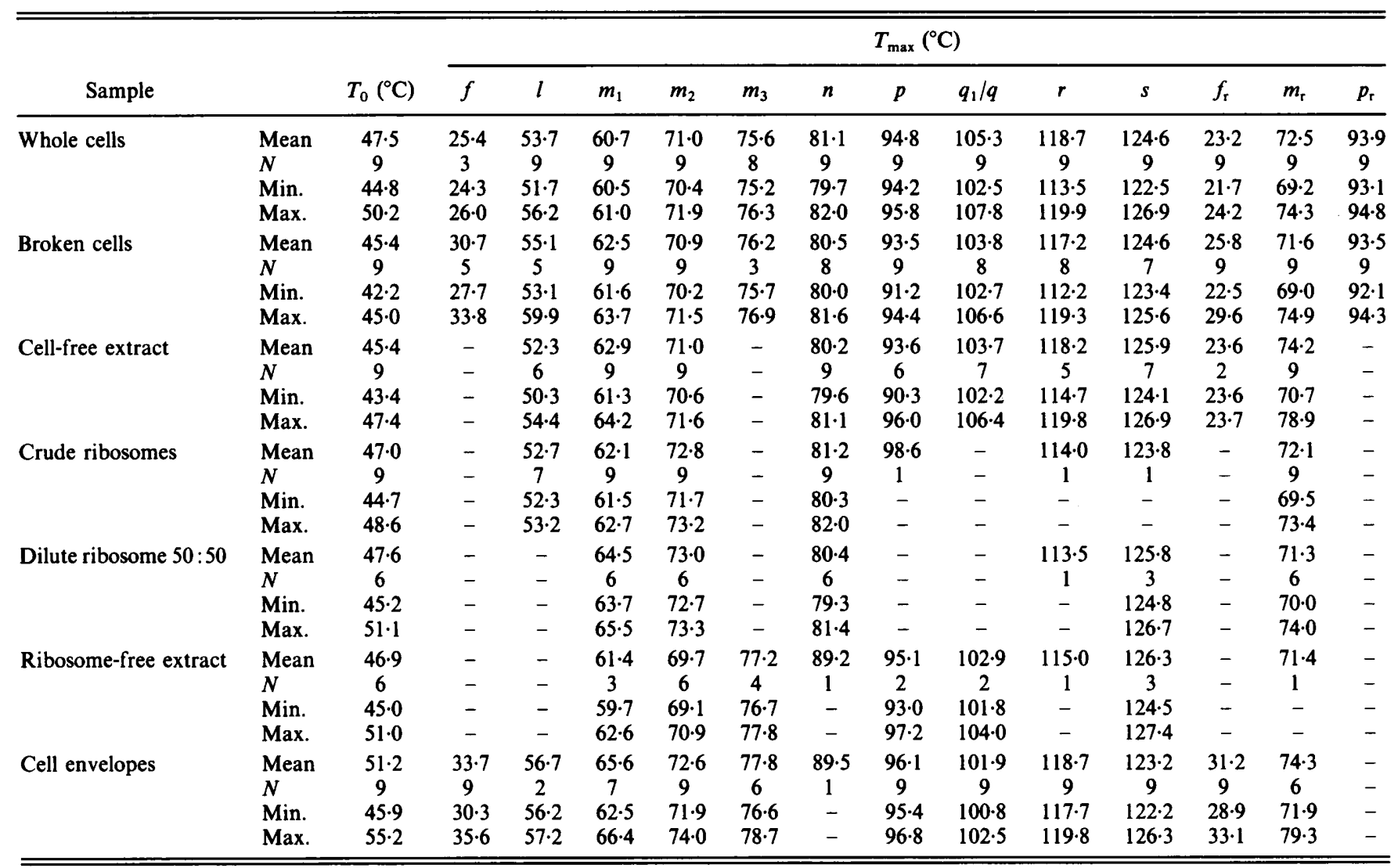

\section{Broken cells}

Broken cell preparations contained more water than whole-cell preparations because buffer was added in their preparation. The dry matter contained approximately the same amounts of RNA and DNA as whole cells, i.e. nuclease activity was not extensive enough to cause a major decrease (but note the increased SD for RNA in Table 1). The protein content was lower: $54 \%$ compared with $58 \%$ in whole cells (Table 1 ).

When cells had been mechanically damaged by freezing and passing through the X-press, there were noticeable changes in the thermogram (Fig. $1 b$ ). $l, m_{3}, q$, $r$ and $s$ were reduced in size while $p$ increased, and the peaks above $p$ were more variable in shape and position. While reversible features $f_{\mathrm{r}}, m_{\mathrm{r}}$ and $p_{\mathrm{r}}$ were visible in all samples, $p_{\mathrm{r}}$ was usually smaller than $p$ and less reproducible in shape than the $p_{\mathrm{r}}$ of whole cells.

\section{Cell-free extract}

This fraction had been treated with DNAase and centrifuged to remove whole cells and most of the cell wall fragments. The dry matter content was lower than that of the broken-cell preparation and, as expected, the DNA content was also lower (Table 1). The protein content was similar to, and RNA content somewhat less than, that of the broken cells. Removal of cell walls might have been expected to increase the proportion of RNA and protein. This was not observed, probably due to loss of ribosomal material with the cell envelopes and 


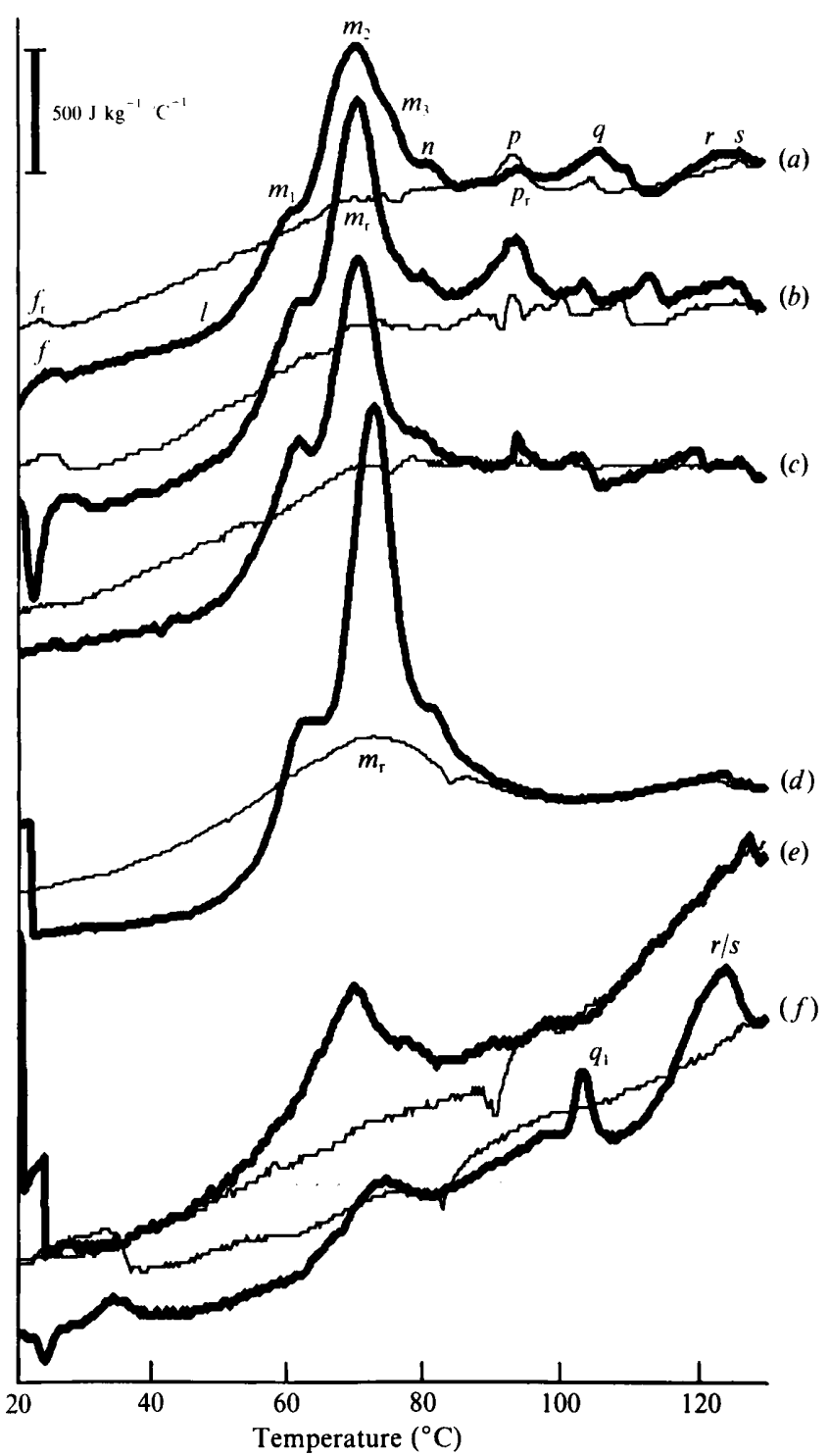

Fig. 1. Thermograms of whole cells and fractions of whole cells of $E$. coli NCTC 8164. (a) Whole cells; (b) broken cells; (c) cell-free extract; $(d)$ crude ribosomes; (e) ribosome-free extract; $(f)$ cell envelopes. The thicker line of each pair is the thermogram obtained during the first heating run; the thinner line is the thermogram obtained after cooling and reheating the sample. The letters indicate thermogram features described in the text. A subscript ' $r$ ' denotes a feature observed during the rerun.

possibly also some loss due to degradative processes. Sucrose gradient analysis showed absorbance peaks typical of ribosomes and a peak near the meniscus which represented small molecules/fragments such as residual tRNA or mRNA and nucleotides from the degradation of DNA and RNA. Absorption of UV by protein would also have contributed to this peak (data not shown).

The main thermogram features of the cell-free extract were peaks similar to $m_{1}, m_{2}$ and $n$ seen in whole and broken cells (Fig. 1c). There was very little reproducible structure at temperatures above $n$ or in the low temperature region, i.e. $f$ and $f_{\mathrm{r}}$ were reduced or absent, as were $p$ and $p_{\mathrm{r}}, q, r$ and $s$. The reversible peak $m_{\mathrm{r}}$, however, was still present in this fraction. Thermogram features $p$ and $p_{\mathrm{r}}$ are believed to be associated with the melting of DNA (Miles et al., 1986) and their absence in DNAase-treated material is therefore as expected. The absence of $f, f_{\mathrm{r}}, q, r$ and $s$ suggests these features may be associated with denaturation of cell envelope components. However, we believe that DNA melting may also contribute to peak $q$ (see Discussion).

\section{Crude ribosomal fraction}

The ribosomes formed a hard pellet and the dry matter content was high, consisting mostly of protein and RNA. Since ribosomes are known to contain $62 \%$ RNA (Noller \& Nomura, 1987), the $38 \%$ RNA content (Table 1) indicates substantial protein contamination.

Thermograms of crude ribosomes (Fig. 1d) showed three major peaks which strongly resembled in shape and position peaks $m_{1}, m_{2}$ and $n$ seen in whole cells. The peaks at $m_{1}$ and $m_{2}$ were 1 to $2{ }^{\circ} \mathrm{C}$ higher than in whole cells and the peak at $m_{2}$ was noticeably sharper. These changes may have been caused by dilution effects and/or changes in the ionic environment on disruption of the cells in buffer. There were noticeable variations between subsamples in the shape of $m_{1}$ (compare the crude ribosome preparations in Figs 1 and 2) and when crude ribosome pellets were diluted 50:50 with buffer, there was a more pronounced separation of peaks $m_{1}$ and $m_{2}$. A small shoulder corresponding to peak $l$ in whole cells was seen in seven of nine ribosome samples.

On cooling and reheating the sample, a very strong broad clear endotherm denoted $m_{\mathrm{r}}$ was seen (Fig. $1 d$ ) (occasionally a small dip was observed in $m_{\mathrm{r}}$, indicating an exothermic reaction, but its position and size were irreproducible). The other apparently reversible peaks $p_{\mathrm{r}}$ and $f_{\mathrm{r}}$, present in whole cells, were absent from ribosomes.

\section{Ribosome-free extract}

The supernatant remaining after removal of ribosomes by centrifugation was too dilute to yield resolvable peaks in DSC and was therefore concentrated by dialysis. The fraction depicted in Fig. 1(e) had about half the dry matter content of whole cells. The main component of the extract was protein $(66 \%)$, with much smaller amounts of RNA (1.8\%) and DNA (0.2\%) (Table 1). Much of the unaccounted dry matter (Table 1) was buffer constituents (the buffer contained $3.7 \%$ dry matter). The low level of RNA (1.8\%) implies that there was little 


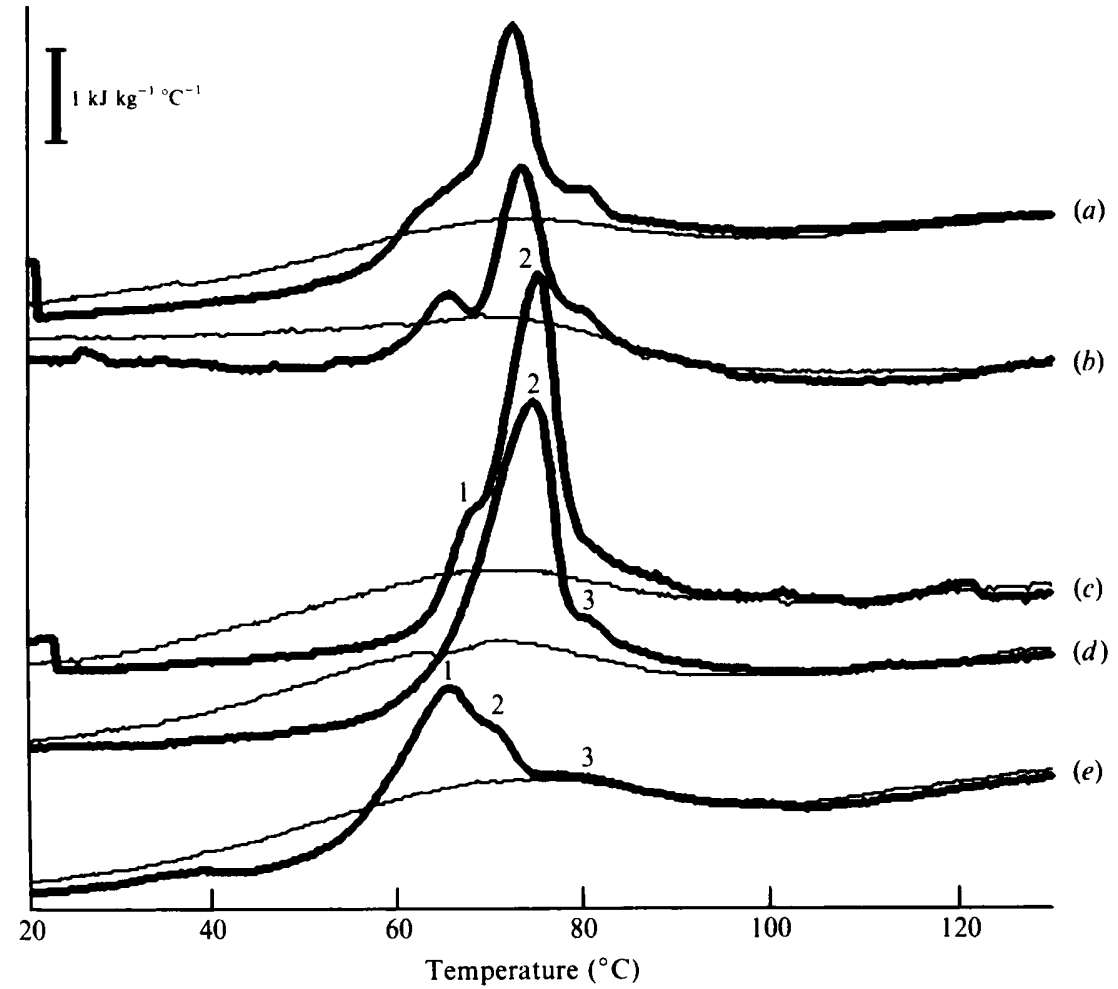

Fig. 2. Thermograms of ribosomes and ribosomal subunits from $E$. coli NCTC 8164. (a) Pellet of crude ribosomes; (b) crude ribosomal pellet diluted 50:50 with buffer; (c) purified $70 \mathrm{~S}$ ribosomes; (d) $50 \mathrm{~S}$ subunits; (e) $30 \mathrm{~S}$ subunits. The thicker line of each pair is the thermogram obtained during the first heating run; the thinner line is the thermogram obtained after cooling and reheating the sample. contamination by residual ribosomes. If we assume that all the RNA was ribosomal in origin, then the concentrated extract contained about $7 \%$ of the ribosomes present in whole cells.

UV-absorbing bands were undetectable following sucrose density-gradient centrifugation of this extract, confirming the very low content of ribosomes in this cell fraction.

The thermogram (Fig. 1e) contained a broad multicomponent peak with a maximum at a mean temperature of $69.7^{\circ} \mathrm{C}$, but no reproducible peaks above $80^{\circ} \mathrm{C}$ or below $60^{\circ} \mathrm{C}$. The rerun showed no reproducible features. The main thermogram feature thus occurred in the same temperature range as features associated with ribosome melting. However, the ribosome content would appear too low to account entirely for this feature and we assume it must also represent denaturation of soluble cytoplasmic proteins.

\section{Cell envelopes}

Cell envelopes showed peaks at $f, f_{\mathrm{r}}, p, q, r$ and $s$, and a broad feature in the region of $m_{3}$ (Fig. $1 f$ ). Some fractions were contaminated with ribosomes as evidenced by a distinct ribosome peak in the thermogram and a high content of RNA in the chemical analysis. The quoted analyses are for samples which were thus contaminated, but the example in Fig. $1(f)$ was largely uncontaminated. The most distinctive feature was an endotherm in the region of peak $q$ seen in whole cells. This feature was much sharper than $q$ and appears to be a single process which we have denoted as $q_{1}$. In the hightemperature region there was a clear endotherm similar in position to, but larger than, peaks $r$ and $s$ seen in whole cells. In the low-temperature region there was a broad peak denoted $f$ which yielded $f_{\mathrm{r}}$ on the rerun. We believe this represents the melting and remelting of membrane phospholipids.

\section{Further examination of cell fractions}

Ribosomes. 70S ribosomes showed a multi-event thermogram with the major process having a maximum at $75.9{ }^{\circ} \mathrm{C}$. The extent of the shoulder on the leading edge of that peak varied between samples, and the trailing edge indicated the presence of at least one other process (Fig. $2 c$ ). The $50 \mathrm{~S}$ subunits showed a similar thermogram but no shoulder was apparent on the leading edge and the extent of the process on the trailing edge was increased. The main peak of the $50 \mathrm{~S}$ subunit occurred at $74.0^{\circ} \mathrm{C}$ and was slightly broader than that of the $70 \mathrm{~S}$, caused mainly by differences in the steepness of the leading edge (Fig. $2 d$ ). The $30 \mathrm{~S}$ subunit showed a still broader peak, with the main peak at $65.6^{\circ} \mathrm{C}$, a substantial shoulder on the trailing edge at $70.7^{\circ} \mathrm{C}$, and a very broad hightemperature process which followed the line of the rerun 
Table 3. Temperatures of onset of thermal denaturation $\left(T_{0}\right)$, temperatures of the peak maxima $\left(T_{\max }\right)$ and enthalpies of denaturation $(\Delta H)$ of ribosomes and ribosomal subunits from E. coli NCTC 8164

The quoted values are the means of measurements of two preparations. $N$ indicates the total number of replicate observations. The numbers 1,2 and 3 heading the columns are not intended to imply that data within a column refer to the same process.

\begin{tabular}{|c|c|c|c|c|c|c|c|c|c|}
\hline \multirow[b]{3}{*}{ Sample } & & \multirow[b]{3}{*}{$\mathrm{T}_{0}\left({ }^{\circ} \mathrm{C}\right)$} & & & & & \multicolumn{3}{|c|}{$\Delta H$ of denaturation } \\
\hline & & & \multicolumn{4}{|c|}{$T_{\max }\left({ }^{\circ} \mathrm{C}\right)$} & \multicolumn{2}{|c|}{$J$ (g dry matter) $)^{-1}$} & \multirow{2}{*}{$\begin{array}{c}\mathrm{J}(\mathrm{g} \text { RNA })^{-1 *} \\
\text { Rerun } \\
\left(m_{\mathrm{r}}\right)\end{array}$} \\
\hline & & & 1 & 2 & 3 & $\begin{array}{c}\text { Rerun } \\
\left(m_{\mathrm{r}}\right)\end{array}$ & Run & $\underset{\left(m_{r}\right)}{\text { Rerun }}$ & \\
\hline $70 \mathrm{~S}$ & $\begin{array}{l}\text { Mean } \\
N \\
\text { Min. } \\
\text { Max. }\end{array}$ & $\begin{array}{c}57 \cdot 7 \\
5 \\
55 \cdot 8 \\
59 \cdot 6\end{array}$ & $\begin{array}{c}68 \cdot 0 \\
4 \\
67 \cdot 6 \\
68 \cdot 8\end{array}$ & $\begin{array}{c}75 \cdot 9 \\
5 \\
75 \cdot 1 \\
76 \cdot 7\end{array}$ & $\begin{array}{c}82 \cdot 1 \\
5 \\
81 \cdot 5 \\
82 \cdot 6\end{array}$ & $\begin{array}{c}70 \cdot 3 \\
5 \\
68 \cdot 6 \\
71 \cdot 5\end{array}$ & $\begin{array}{r}42 \\
5 \\
40 \\
47\end{array}$ & $\begin{array}{r}23 \\
5 \\
21 \\
26\end{array}$ & $\begin{array}{l}31 \\
- \\
- \\
-\end{array}$ \\
\hline $50 \mathrm{~S}$ & $\begin{array}{l}\text { Mean } \\
N \\
\text { Min. } \\
\text { Max. }\end{array}$ & $\begin{array}{c}54 \cdot 5 \\
5 \\
51 \cdot 6 \\
55 \cdot 8\end{array}$ & $\begin{array}{l}- \\
- \\
- \\
-\end{array}$ & $\begin{array}{c}74 \cdot 0 \\
5 \\
73 \cdot 6 \\
74 \cdot 6\end{array}$ & $\begin{array}{c}81 \cdot 2 \\
5 \\
80 \cdot 9 \\
81 \cdot 5\end{array}$ & $\begin{array}{c}71 \cdot 7 \\
5 \\
71 \cdot 1 \\
72 \cdot 3\end{array}$ & $\begin{array}{r}43 \\
4 \\
42 \\
45\end{array}$ & $\begin{array}{r}23 \\
5 \\
21 \\
25\end{array}$ & $\begin{array}{l}- \\
- \\
- \\
-\end{array}$ \\
\hline $30 \mathrm{~S}$ & $\begin{array}{l}\text { Mean } \\
N \\
\text { Min. } \\
\text { Max. }\end{array}$ & $\begin{array}{c}48 \cdot 4 \\
4 \\
44 \cdot 3 \\
53 \cdot 1\end{array}$ & $\begin{array}{c}65 \cdot 6 \\
4 \\
65 \cdot 2 \\
66 \cdot 4\end{array}$ & $\begin{array}{c}70 \cdot 7 \\
4 \\
70 \cdot 5 \\
70 \cdot 9\end{array}$ & $\begin{array}{c}81 \cdot 6 \\
4 \\
80 \cdot 4 \\
82 \cdot 6\end{array}$ & $\begin{array}{c}71 \cdot 5 \\
4 \\
68 \cdot 5 \\
75 \cdot 2\end{array}$ & $\begin{array}{r}36 \\
4 \\
36 \\
37 \\
37\end{array}$ & $\begin{array}{r}22 \\
4 \\
21 \\
24\end{array}$ & $\begin{array}{l}- \\
- \\
- \\
-\end{array}$ \\
\hline
\end{tabular}

* $\Delta H\left[\mathrm{~J}(\mathrm{~g} \mathrm{RNA})^{-1}\right]=100 / \%$ RNA by mass $\times \Delta H\left[\mathrm{~J}(\mathrm{~g} \text { dry mass })^{-1}\right]$.

(Fig. 2e). The thermal stability of ribosomal particles, based on either $T_{\max }$ of the main peak or $T_{0}$ values, thus increased in the order $30 \mathrm{~S}<50 \mathrm{~S}<70 \mathrm{~S}$. All subunits showed broad peaks on reheating with the same shape and position as peak $m_{\mathrm{r}}$ observed in whole cells. We believe this process is the reversible denaturation of ribosomal RNA (see Discussion). Thermal data for denaturation of ribosomes and subunits are summarized in Table 3.

Sucrose density-gradient analysis revealed that some $30 \mathrm{~S}$ particles (approx. 17\%) were present in the $70 \mathrm{~S}$ preparation, possibly caused by the effect of pressure on the $30 \mathrm{~S}$ and $50 \mathrm{~S}$ association, since there is a large volume increase in association (Van Holde \& Hill, 1974). The $30 \mathrm{~S}$ preparation appeared homogeneous after the second gradient run but the 50S band was much broader and more diffuse. This fraction may therefore have been impure, although we were unable to detect any heterogeneity by separately recentrifuging the upper and lower portion of the band.

The chemical analysis of the different preparations given in Table 4 revealed that the ratio of RNA to protein in $70 \mathrm{~S}, 50 \mathrm{~S}$ and $30 \mathrm{~S}$ particles was approximately $2: 1$. This is higher than the accepted ratio of about $1 \cdot 6: 1$ (Noller \& Nomura, 1987), possibly indicating some loss of ribosomal protein during preparation and storage. The enthalpy measurements for denaturation of $70 \mathrm{~S}$ and $50 \mathrm{~S}$ particles were similar, whilst that for the $30 \mathrm{~S}$ subunit was lower. The enthalpy for the $m_{\mathrm{r}}$ endotherm was similar for all three particles. The value of $23 \mathrm{~J}$ ( $\mathrm{g}$ dry matter) ${ }^{-1}$ (70S component) was equivalent to $31 \mathrm{~J}^{(\mathrm{g} R N A)^{-1}}$.

\section{Cell envelope components}

Thermograms of cell envelopes, lipid and peptidoglycan are shown in Fig. 3. If peaks $f$ and $f_{\mathrm{r}}$ were due to the melting of membrane lipid, we would expect the peak maxima to vary depending on growth temperature. When cells were grown at $20^{\circ} \mathrm{C}$, the maximum of peak $f$ was 5 to $8^{\circ} \mathrm{C}$ lower than in cells grown at $37^{\circ} \mathrm{C}$ (Fig. $3 a$, $b$ ). The rerun endotherms $\left(f_{\mathrm{r}}\right)$ were broader than those observed on the first run $(f)$ and occurred at a slightly lower temperature. A difference in $T_{\max }$ was still observed, however: $31.6{ }^{\circ} \mathrm{C}$ for cells grown at $37^{\circ} \mathrm{C}$, compared with $25.4{ }^{\circ} \mathrm{C}$ for cells grown at $20^{\circ} \mathrm{C}$.

Extracted membrane lipid exhibited a sharp peak at $37.9{ }^{\circ} \mathrm{C}$, whereas the rerun peak was broader and had a lower peak maximum $\left(30.8^{\circ} \mathrm{C}\right)$ (Fig. $3 c$ c). Thermogram features $f$ and $f_{\mathrm{r}}$ are thus associated with the melting and remelting of membrane lipid. The other main thermogram features (described in the preceding section) were unaffected by growth temperature.

The peptidoglycan preparation, which when viewed under the electron microscope showed the expected 'empty bag' appearance, revealed little structure on the 
Table 4. Temperatures of peak maxima $\left(T_{\max }\right)$, and enthalpies of denaturation $(\Delta H)$ of nucleic acids of $E$. coli in glutamate buffer

The quoted values are means, maxima and minima of $N$ observations.

\begin{tabular}{|c|c|c|c|c|c|}
\hline \multirow[b]{2}{*}{ Sample } & & \multicolumn{2}{|r|}{ Run } & \multicolumn{2}{|r|}{ Rerun } \\
\hline & & $T_{\max }\left({ }^{\circ} \mathrm{C}\right)$ & $\begin{array}{c}\Delta H^{*} \\
\mathrm{~J}(\mathrm{~g} \text { nucleic acid })^{-1}\end{array}$ & $T_{\max }\left({ }^{\circ} \mathrm{C}\right)$ & $\begin{array}{c}\Delta H^{*} \\
\mathrm{~J}(\mathrm{~g} \text { nucleic acid) })^{-1}\end{array}$ \\
\hline DNA & $\begin{array}{l}\text { Mean } \\
N \\
\text { Min. } \\
\text { Max. }\end{array}$ & $\begin{array}{c}95 \cdot 3 \\
4 \\
95 \cdot 1 \\
95 \cdot 7\end{array}$ & $\begin{array}{r}64 \\
4 \\
53 \\
72\end{array}$ & $\begin{array}{c}95 \cdot 3 \\
6 \\
95 \cdot 0 \\
95 \cdot 7\end{array}$ & $\begin{array}{r}40 \\
6 \\
24 \\
61\end{array}$ \\
\hline tRNA & $\begin{array}{l}\text { Mean } \\
N \\
\text { Min. } \\
\text { Max. }\end{array}$ & $\begin{array}{c}78 \cdot 7 \\
3 \\
77 \cdot 7 \\
79 \cdot 3\end{array}$ & $\begin{array}{r}34 \\
2 \\
28 \\
41\end{array}$ & $\begin{array}{c}77 \cdot 6 \\
3 \\
77 \cdot 4 \\
77 \cdot 9\end{array}$ & $\begin{array}{r}35 \\
3 \\
31 \\
38\end{array}$ \\
\hline rRNA & $\begin{array}{l}\text { Mean } \\
N \\
\text { Min. } \\
\text { Max. }\end{array}$ & $\begin{array}{c}72 \cdot 6 \\
3 \\
71 \cdot 6 \\
73 \cdot 1\end{array}$ & $\begin{array}{r}28 \\
3 \\
25 \\
33\end{array}$ & $\begin{array}{c}72 \cdot 4 \\
3 \\
71 \cdot 2 \\
73 \cdot 3\end{array}$ & $\begin{array}{r}32 \\
3 \\
29 \\
33\end{array}$ \\
\hline
\end{tabular}

- $\Delta H\left[\mathrm{~J}(\mathrm{~g} \text { nucleic acid })^{-1}\right]=100 / \%$ nucleic acid in solution $\times \Delta H\left[\mathrm{~J}(\mathrm{~g} \text { solution })^{-1}\right]$.

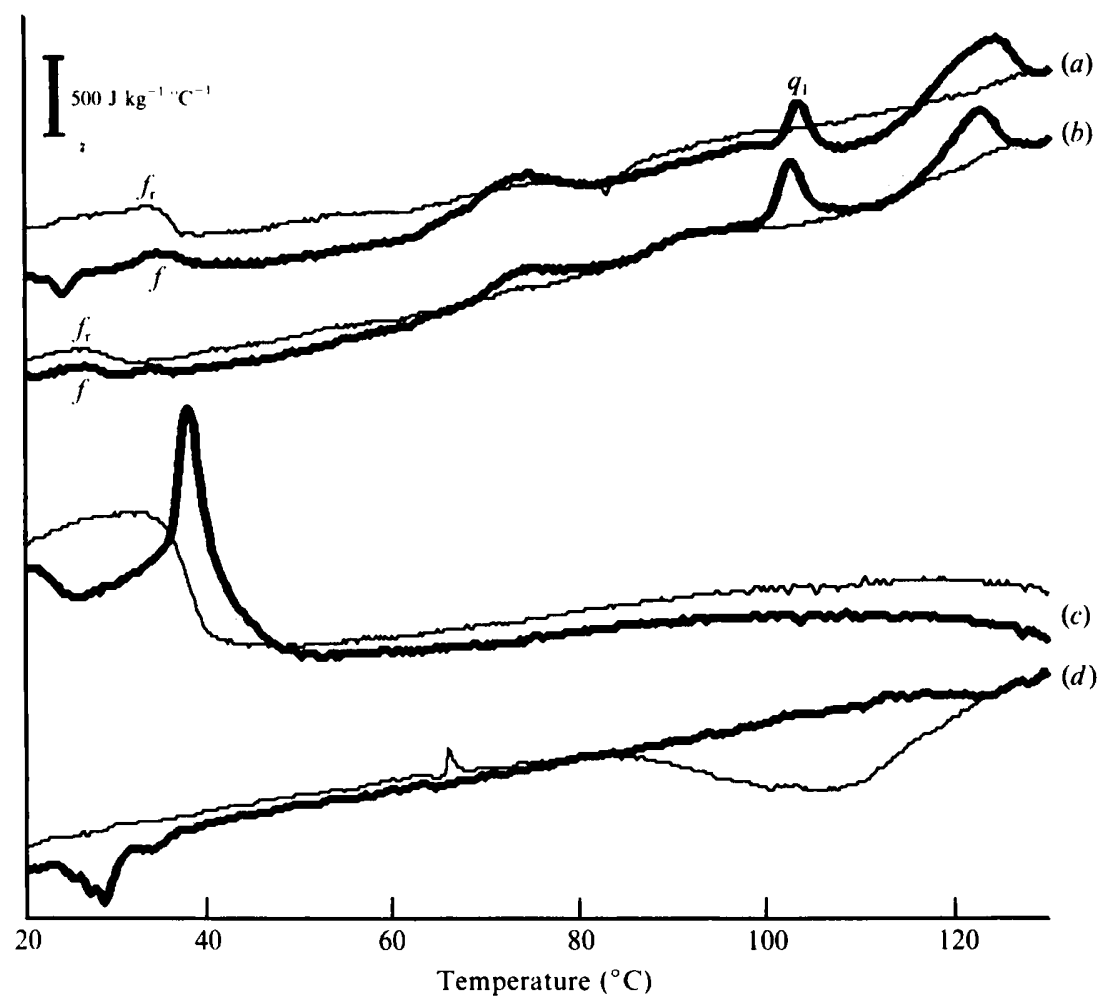

Fig. 3. Thermograms of E. coli NCTC 8164 cell envelopes and constituents. (a) Cell envelopes prepared from cells grown at $37^{\circ} \mathrm{C} ;(b)$ cell envelopes prepared from cells grown at $20^{\circ} \mathrm{C} ;(c)$ lipid extracted from cell envelopes; $(d)$ peptidoglycan. The thick line is the thermogram obtained during the first heating run; the thinner line is the rerun thermogram. first scan, except a fairly sharp exotherm at $28^{\circ} \mathrm{C}$ which varied in size and appearance between runs (Fig. $3 d$ ). Similar small exotherms were occasionally seen in whole cells or broken-cell fractions (Fig. 1). On cooling and rescanning, a broad exotherm was seen at high temperatures. This feature had no obvious relationship with any feature seen in whole cells or envelope fractions.

\section{Nucleic acids}

Thermograms of DNA, rRNA and tRNA in glutamate buffer are shown in Fig. 4 and the thermal data are summarized in Table 4. DNA yielded an apparently single endothermic process with a maximum of $95.3{ }^{\circ} \mathrm{C}$ and an enthalpy of $64 \mathrm{~J}$ ( $\mathrm{g}$ dry matter $)^{-1}$. On cooling and 

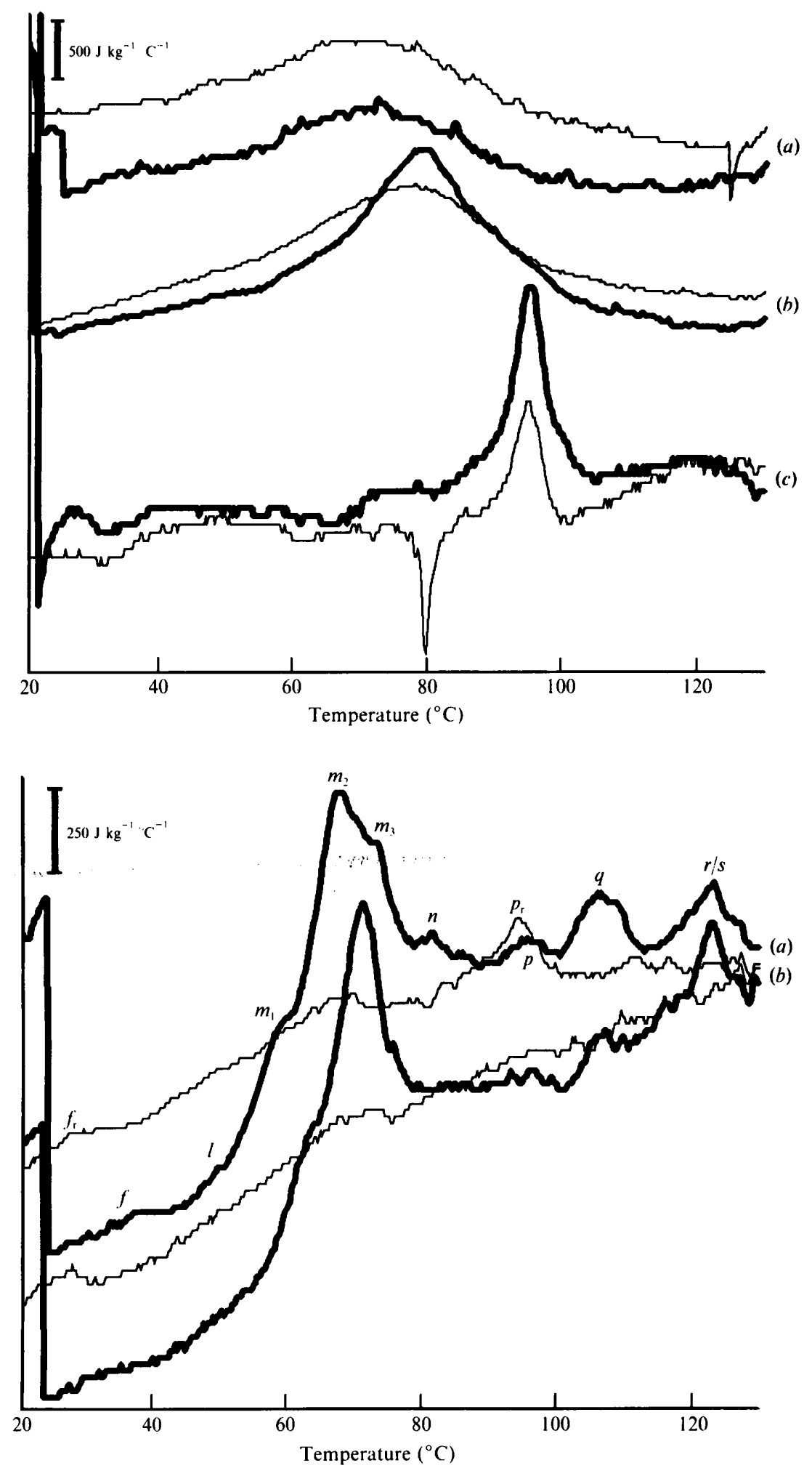

Fig. 4. Thermograms of nucleic acids of $E$. coli in glutamate buffer. (a) rRNA; (b) tRNA; (c) DNA. The thick line is the thermogram obtained during the first heating run; the thinner line is the rerun thermogram.

Fig. 5. Thermograms of (a) normal cells and (b) minicells of $E$. coli DS410.

rescanning the same preparation, an exothermic process occassionally preceded the main endotherm, which was reduced in size to $40 \mathrm{~J}$ (g dry matter) ${ }^{-1}$ but occurred at the same temperature. The melting of DNA was therefore not fully reversible in glutamate buffer, and the remelting process was more complex than the initial melting.

Ribosomal RNA yielded very broad endotherms on both the run and rerun whilst tRNA yielded a somewhat sharper peak on the run, which became broader on the 
Table 5. Temperatures of onset of thermal denaturation $\left(T_{0}\right)$, temperatures of peak maxima $\left(T_{\max }\right)$, and enthalpies of denaturation $(\Delta H)$ of normal cells and minicells of E. coli DS410

The data for whole cells are means of three replicates of a single preparation. The minicell data are of two preparations replicated twice and three times. $p$ was small in both minicells and normal cells and measurements of $T_{\max }$ were made with difficulty. $N$ denotes the number of observations for each characteristic.

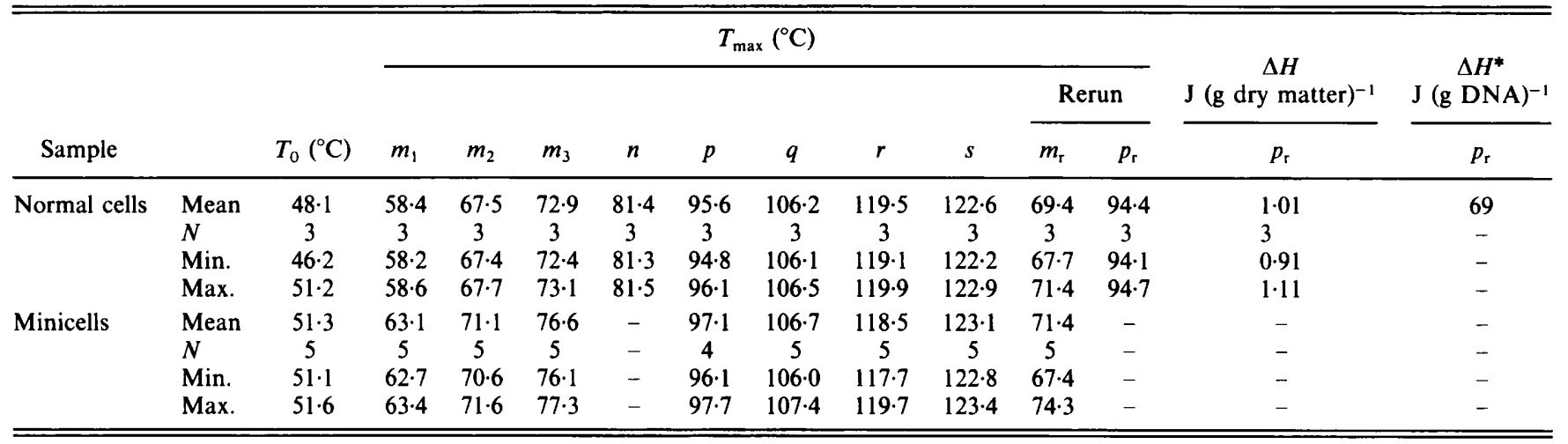

$* \Delta H\left[\mathrm{~J}(\mathrm{~g} \mathrm{DNA})^{-1}\right]=100 / \%$ DNA by mass $\times \Delta H\left[\mathrm{~J}(\mathrm{~g} \text { dry mass })^{-1}\right]$.

Table 6. Chemical composition of minicells and normal cells of E. coli DS410

The values given are the means $( \pm \mathrm{SD})$ of three (dry matter) or four replicates.

\begin{tabular}{|c|c|c|c|c|c|}
\hline \multirow[b]{2}{*}{ Sample } & \multirow{2}{*}{$\begin{array}{l}\text { Dry matter } \\
\text { content } \\
\text { (\% by mass) }\end{array}$} & \multicolumn{3}{|c|}{$\begin{array}{l}\text { Composition as a } \\
\text { percentage of } \\
\text { dry matter }\end{array}$} & \multirow{2}{*}{$\begin{array}{l}\text { Percentage } \\
\text { of total } \\
\text { dry matter } \\
\text { accounted for }\end{array}$} \\
\hline & & Protein & DNA & RNA & \\
\hline Normal cells & $\begin{array}{c}22 \\
\pm 0 \cdot 3\end{array}$ & $\begin{array}{c}66 \\
\pm 1 \cdot 8\end{array}$ & $\begin{array}{r}1.47 \\
\pm 0.02\end{array}$ & $\begin{array}{c}11 \\
\pm 5.4\end{array}$ & 79 \\
\hline Minicells & $\begin{array}{c}23 \\
\pm 0.3\end{array}$ & $\begin{array}{c}60 \\
\pm 24\end{array}$ & $\begin{array}{r}0.12 \\
\pm 0.03\end{array}$ & $\begin{array}{c}16 \\
\pm 5.4\end{array}$ & 76 \\
\hline
\end{tabular}

rerun. The $T_{\max }$ for rRNA $\left(72.6^{\circ} \mathrm{C}\right)$ was lower than that for tRNA $\left(78.7^{\circ} \mathrm{C}\right)$. The mean enthalpy for rRNA [30 J (g dry matter) $)^{-1}$ ] was similar to the value of $31 \mathrm{~J}$ (g RNA) ${ }^{-1}$ calculated from ribosome melting data (Table 3 ) and slightly lower than the mean for tRNA [35 J (g dry matter $)^{-1}$. Both were substantially lower than the value for DNA. No reduction in enthalpy occurred on remelting tRNA or IRNA; the processes were thus substantially reversible.

\section{Minicells}

Minicells contain little or no DNA and, by comparison with normal cells, offer a means of identifying thermogram features associated with the intracellular melting of DNA. Thermograms of normal cells and minicells (strain DS410) are compared in Fig. 5 and the thermal data are summarized in Table 6. There were several differences in detail between the two thermograms but the main finding was that minicells showed no peak $p_{\mathrm{r}}$ on the rerun thermogram whilst, on the first heating run, there was no peak $n$ in the ribosomal region and peaks $p$ and $q$ were much reduced.

The measured $T_{\max }$ value for $p$ was slightly higher in minicells than in normal cells, whereas $q$ and $s$ were very similar and $r$ was slightly lower. However, peak $p$ was very small in both minicells and normal cells, and measurements of $T_{\max }$ were made with difficulty. We cannot be confident therefore that these differences are significant. The enthalpy of peak $p_{\mathrm{r}}$ in normal cells was $\left.69 \mathrm{~J}^{(\mathrm{g} \mathrm{DNA}}\right)^{-1}$ (Table 5) which is very close to the value of $64 \mathrm{~J} \mathrm{(g} \mathrm{DNA})^{-1}$ obtained when pure DNA was heated for the first time in glutamate buffer (Table 4). Chemical analysis confirmed that minicells contained less than one-tenth the amount of DNA found in normal cells (Table 6). The residual amount may have been due to some small whole cells remaining in the preparation. The absence of peak $p_{\mathrm{r}}$ from minicells confirms that this feature is associated with the melting of intracellular DNA.

\section{Discussion}

The purpose of this work was to identify cell organelles or structures whose denaturation was responsible for the characteristic features seen in thermograms of whole bacterial cells. To do this thermograms of various cell fractions have been examined for a correspondence between thermogram features in these fractions and those observed in whole cells. 
The processes represented by peaks $f$ and $f_{\mathrm{r}}$ observed in the low-temperature region in whole cells were also seen in envelope fractions but were absent from ribosomes, cell-free extract and ribosome-free extract. Similar features were observed by Melchior \& Steim (1976) in calorimetric studies of whole cells and were attributed to the melting of membrane lipids. This conclusion is confirmed by our observation that the peak maxima vary depending on growth temperature, and by the similar melting behaviour of lipids extracted from $E$. coli cells. The observation that the lipid endotherm in cells grown at $37^{\circ} \mathrm{C}$ extended to higher temperatures than in cells grown at $20^{\circ} \mathrm{C}$ (Fig. 3) concurs with several other reports on the effect of growth temperature on the melting temperature of membrane lipids (Jackson \& Cronan, 1978; Halverson et al., 1978; Marr \& Ingraham, 1962) and is probably caused by an increased proportion of unsaturated fatty acids in the lipids of the $20^{\circ} \mathrm{C}$ sample.

Although the DSC scans were started at $5{ }^{\circ} \mathrm{C}$, observations were limited to temperatures above about $20^{\circ} \mathrm{C}$ because of initial instrumental transients, and there was an indication that part of the lipid endotherms occurred below this temperature (see Fig. 5, also Melchior \& Steim, 1976). In order to observe the transition at lower temperatures, unobscured by transients or the ice/water transition, it would have been necessary to incorporate an antifreeze agent in the specimen (e.g. Steim, 1972).

In the temperature range studied, the area of $f_{\mathrm{r}}$ was generally larger than $f$, presumably because part of the lower temperature endotherm of $f$ melted at a higher temperature on reheating. A similar observation was made by Melchior \& Steim (1976) on reheating whole cells, and may be caused by different proportions of polymorphic crystalline forms of lipids in unheated and heated cell walls. Alternatively, denaturation of membrane proteins on heating may have affected the packing arrangement of the phospholipids on cooling.

The temperature of peak maxima for melting of membrane lipids or extracted lipids were lower on the rerun than on the run, and this may also be related to changes in the crystalline form induced by heating and rapid cooling.

The rather broad endotherm caused by the melting of membrane lipids quite often contained an additional exothermic process occurring between 25 and $29^{\circ} \mathrm{C}$. This superimposed feature may have been caused by a change in state of the peptidoglycan component of the cell envelope since it was always present in the few peptidoglycan preparations that we examined. This novel feature is particularly interesting because it occurs within the normal growth range of the bacterium.

Peaks $m_{1}, m_{2}$ and $n$ seen in whole cells are caused by melting of the ribosomes. Similar, but larger features were present in the crude ribosome fraction but were much reduced or absent in the ribosome-free supernatant. However, it was difficult to make precise correlations between thermogram features observed in purified preparations and those seen in whole cells. It was apparent that changes in the appearance of peaks and in their $T_{\max }$ values occurred during the fractionation procedures. Thus the $T_{\max }$ of the main peak $m_{2}$ was about $5^{\circ} \mathrm{C}$ higher in purified 70S particles than within whole cells. This may have been caused by differences in melting behaviour in glutamate buffer compared with that in cytoplasm. In crude ribosome preparations, which would have contained both glutamate buffer and cytoplasm, the $T_{\max }$ was of intermediate value. Thermograms of ribosomes were also affected by the concentration of the sample. In pelleted ribosomes, peak $m_{1}$ appeared as a shoulder at about $62{ }^{\circ} \mathrm{C}$ preceding the main peak $m_{2}$, whereas in material that had been diluted 50:50 with buffer and resuspended, $m_{1}$ appeared as a distinct peak with a $T_{\max }$ of $64.5^{\circ} \mathrm{C}$ (Fig. 2).

The $T_{\max }$ and shape of $m_{1}$ in whole cells are very similar to those of the first peak in the crude ribosome preparation (Fig. 1, Table 2) and the $T_{\max }$ of the first peak observed in diluted crude ribosomes $\left(64.5^{\circ} \mathrm{C}\right)$ is close to that of the purified $30 \mathrm{~S}$ subunit $\left(65.6^{\circ} \mathrm{C}\right)$. We therefore suggest that peak $m_{1}$ seen in whole cells represents melting of the $30 \mathrm{~S}$ ribosomal subunit.

The main thermogram feature seen in whole cells, peak $m_{2}$, was similar to the main feature seen in crude ribosomes, purified $70 \mathrm{~S}$ particles and $50 \mathrm{~S}$ subunits. At first sight it would be tempting to identify $m_{2}$ with melting of the 50S subunit, but it is clear that denaturation of the $70 \mathrm{~S}$ ribosome cannot simply be divided into the separate denaturation of $30 \mathrm{~S}$ and $50 \mathrm{~S}$ subunits. The shoulder on the leading edge of the $70 \mathrm{~S}$ thermograms is too small to represent denaturation of all the $30 \mathrm{~S}$ component. Part of the melting process of the $30 \mathrm{~S}$ subunit must therefore occur within the larger, main peak of the $70 \mathrm{~S}$ thermogram. The temperatures of the shoulder and main peak of the 70S particle are slightly higher than the corresponding maxima in the $30 \mathrm{~S}$ and $50 \mathrm{~S}$ subunits. The thermostability of the $70 \mathrm{~S}$ particle would thus appear slightly greater than the sum of its constituent parts.

Several workers have reported that the $30 \mathrm{~S}$ ribosomal subunit is more heat-labile than the $50 \mathrm{~S}$ subunit and Verrips \& Brevoort (1979) proposed an inactivation scheme based on denaturation of the $30 \mathrm{~S}$ subunit followed by hydrolysis of 16S RNA. Exposure of cells of Salmonella typhimurium to mild heat $\left(48^{\circ} \mathrm{C}\right)$ in phosphate buffer results in selective destruction of the $30 \mathrm{~S}$ ribosomal subunit (Tomlins \& Ordal, 1976). This was ascribed to an indirect effect arising from loss of 
magnesium from the cell followed by ribonuclease attack on the destabilized 30S subunit. However, isolated $30 \mathrm{~S}$ particles obtained from both wild-type and ribonucleasenegative strains of $E$. coli were also more labile than the corresponding 50S subunits (Tamaoki \& Miyazawa, 1966; Tal, 1969). We observed that the thermal stability of the ribosomal particles increases in the order $30 \mathrm{~S}<50 \mathrm{~S}<70 \mathrm{~S}$. This is in agreement with the spectroscopic determinations of ribosome melting by Leon $\&$ Brock (1967). Their reported $T_{\max }$ values for denaturation were 64,68 and $72{ }^{\circ} \mathrm{C}$ for $30 \mathrm{~S}, 50 \mathrm{~S}$ and $70 \mathrm{~S}$ particles, respectively. Our corresponding $T_{\max }$ values for the main peaks were $65.6,74.0$ and $75.9^{\circ} \mathrm{C}$. Tal (1969) reported that the $T_{\mathrm{m}}$ for $50 \mathrm{~S}$ subunits was only $1{ }^{\circ} \mathrm{C}$ higher than for $30 \mathrm{~S}$ subunits derived from $E$. coli MRE600 (the original designation of the strain used in the present work). $T_{\mathrm{m}}$ values in that work were determined optically on dilute suspensions or ribosomes in a dilute buffer (1 mM-Tris/acetate, $\mathrm{pH} 7 \cdot 2$ ). There is thus some corroborative evidence that the thermal stabilities of the two ribosomal subunits differ from one another and from the complete particle. It is not clear why the associated $70 \mathrm{~S}$ particle should be more heat stable than its constituent subunits but it is interesting that streptomycin, which inhibits the dissociation process, enhances the heat resistance of ribosomes from streptomycin-sensitive strains of $E$. coli (Wolfe \& Hahn, 1968).

tRNA occurs in the cell at a concentration of about $3 \%$ of the dry matter, sufficient to cause a discernible peak. The $T_{\max }$ of peak $m_{3}$ observed in the ribosomal region in whole cells (at $76^{\circ} \mathrm{C}$ ) is close to that of tRNA $\left(78^{\circ} \mathrm{C}\right)$. Peak $m_{3}$ is also reduced on breaking the cells, which could correspond to enzymic breakdown of tRNA. Although this interpretation is consistent with the facts, we propose it only tentatively.

Thermograms of whole cells contained a broad, clear endotherm denoted $m_{\mathrm{r}}$. This feature was also present, and very obvious, in rerun samples of crude ribosomes and in purified $70 \mathrm{~S}, 50 \mathrm{~S}$ and $30 \mathrm{~S}$ particles. We believe $m_{\mathrm{r}}$ represents the remelting of ribosomal RNA for the following reasons: (1) the peak was broad and reversible and hence similar to the peak observed with pure rRNA (Fig. 4); (2) the $T_{\max }$ value for $m_{\mathrm{r}}$ in whole cells was $72.5^{\circ} \mathrm{C}$, similar to the $T_{\max }$ of the reversible peaks observed in $70 \mathrm{~S}, 50 \mathrm{~S}$ and $30 \mathrm{~S}$ subunits $(70.3,71.7$ and $71.5^{\circ} \mathrm{C}$, respectively) and similar to the $T_{\max }$ of pure rRNA $\left(72.6{ }^{\circ} \mathrm{C}\right)$; and (3) the enthalpy of the reversible peak from $70 \mathrm{~S}$ subunits [31 $\left.\mathrm{J}^{(\mathrm{g} R N A}\right)^{-1}$ ] was similar to the value obtained with pure rRNA [ $30 \mathrm{~J}(\mathrm{~g} \mathrm{RNA})^{-1}$ ]. A broad endotherm similar to $m_{\mathrm{r}}$ was shown in one of the figures presented by Melchior \& Steim (1976) and was attributed to reversible protein denaturation. We believe that interpretation to be incorrect, for the reasons given above.
The enthalpy of $70 \mathrm{~S}$ ribosome denaturation [ $42 \mathrm{~J}$ ( $\mathrm{g}$ dry matter $)^{-1}$ ] is greater than that of the RNA component [23 $\mathrm{J}$ ( $\mathrm{g}$ dry matter $\left.)^{-1}\right]$. If we assume that heat-denatured rRNA resumes its original tertiary structure on cooling (which is likely to be at least partially true since deproteinized 16S RNA is known to adopt a similar conformation to that in the $30 \mathrm{~S}$ subunit and $30 \mathrm{~S}$ subunits can be reconstituted from heat-denatured RNA; Schlessinger, 1960; Barritault et al., 1979), then approximately half the enthalpy of ribosome denaturation is associated with protein denaturation and/or disruption of higherorder interactions, e.g. protein-RNA, protein-protein and long-range RNA-RNA interactions. The enthalpy change associated with melting of free rRNA [mean value, $30 \mathrm{~J}(\mathrm{~g} \mathrm{RNA})^{-1}$ ] is less than that for DNA [ $62 \mathrm{~J} \mathrm{(g}$ DNA $)^{-1}$, presumably reflecting differences in helical content.

Peak $l$ appeared as a slight inflexion on the leading edge of the ribosome melting process and was seen in whole cells and crude ribosomes. It was absent from purified 70S particles, however, and is therefore not associated with ribosome denaturation. Its presence was somewhat sporadic and we have been unable to identify it with any particular cell structure.

In previous publications (Miles et al., 1986; Mackey et al., 1988) we proposed that peak $p$ at approximately $95^{\circ} \mathrm{C}$ and $p_{\mathrm{r}}$ occurring at $94^{\circ} \mathrm{C}$ on the rerun, were associated with the intracellular melting of DNA. The evidence identifying $p_{\mathrm{r}}$ with DNA melting is as follows: (1) it is an apparently reversible process, as is the melting of DNA; (2) the $T_{\max }$ of $p_{\mathrm{r}}$ in $E$. coli is within a range predicted from its $\mathrm{G}+\mathrm{C}$ content and internal ionic strength; (3) the $T_{\max }$ values of peaks similar to $p_{\mathrm{r}}$ in other microbes were linearly correlated with the $G+C$ content of their DNA; and (4) the mass of DNA calculated from the enthalpy of $p_{\mathrm{r}}$ is in close agreement with that obtained by chemical analysis. The results in this paper support this identification in two respects. First, $p_{\mathrm{r}}$ was absent in minicells but present in whole cells, coinciding with the expected and measured reduction of DNA in minicells. Second, $p_{\mathrm{r}}$ disappeared after DNAase treatment.

We also noted previously (Miles et al., 1986; Mackey et al., 1988) that $p_{\mathrm{r}}$ was larger than $p$ and interpreted this to mean that the melting of DNA during the first heating run was not a single process, possibly because parts of the DNA were stabilized by virtue of differences in physical state or by interaction with other molecules (e.g. proteins or polyamines). Once these stabilizing forces had been disrupted by heating, subsequent remelting occurred as a simpler process giving a sharper and larger peak. In this work we observed that peak $p$ increased in size following breakage of the cells, i.e. it more closely resembled $p_{\mathrm{r}}$. It would appear that DNA-stabilizing 
interactions are disturbed by the physical changes attending freezing and disruption of the cells. Alternatively, stabilizing interactions may be affected by enzymes that are released or activated in the broken-cell preparation.

Although peak $p$ is at least partly caused by the melting of DNA there are two lines of evidence suggesting that other processes may contribute to the endotherm. Firstly, a small peak at $96^{\circ} \mathrm{C}$ was observed in cell walls and this could contribute to $p$ in whole cells even though that peak occurs at $95^{\circ} \mathrm{C}$. Secondly, the minicells, which contain little DNA, also showed a peak at $97^{\circ} \mathrm{C}$. We therefore propose that $p$ is a multicomponent peak comprising at least two components, one of which is DNA, and the other a component of the cell wall.

Peak $q$ at around $105^{\circ} \mathrm{C}$ in whole cells is also multicomponent. The pronounced peak $q_{1}$ at $101.9^{\circ} \mathrm{C}$ in cell walls undoubtedly contributes to $q$, and this component is not DNA or lipid or peptidoglycan. DNA, stabilized within the cell, also probably contributes to $q$, since on breaking (and disruption of stabilizing interactions) $q$ is reduced and $p$ is increased. Supporting evidence that DNA melting might contribute to peak $q$ was obtained by heating cells to intermediate temperatures and observing changes in the areas of peaks $q$ and $p_{\mathrm{r}}$ : a progressive decrease in area of $q$ was accompanied by a corresponding increase in $p_{\mathrm{r}}$ (data not shown). There is a possible third component of $q$, because a peak at $104^{\circ} \mathrm{C}$ occurred in the cell-free extract and this contained little cell wall component and no DNA since it had been DNAase treated. This component of $q$ is probably caused by protein.

The multicomponent process designated $r / s$ in whole cells was much reduced in the cell-free extract but present and magnified in the cell envelope fraction. This series of endotherms is therefore associated with denaturation of cell wall components that are not peptidoglycan or lipid, because these endotherms were absent in those fractions. Denaturation of a cell-wall-associated thermostable protein may be responsible, but since $r / s$ is reduced following breakage, a possible contribution by nucleic acid cannot be ruled out, by analogy with the reasons given above for peak $q$. However, $r / s$ is not entirely caused by DNA because the feature was observed in minicells which lack DNA.

On cooling and reheating preparations of peptidoglycan, a large exothermic process occurred between 85 and $125^{\circ} \mathrm{C}$. A similar exothermic process was not observed during reheating of crude envelope fractions. It may have been too small to detect or the peptidoglycan structure may have been physically constrained by interaction with other structural elements of the cell envelope, and thus prevented from undergoing the exothermic process.
The observations recorded in this paper have allowed us to identify some of the main thermogram features associated with the thermal denaturation of $E$. coli cells. We can now begin to place these denaturation events in a time/temperature sequence as follows.

When cells are heated for the first time there is a broad endotherm beginning below $20^{\circ} \mathrm{C}$ and extending to just above $40{ }^{\circ} \mathrm{C}$ that is caused by the melting of membrane lipid. Superimposed on this is an exothermic process associated with a change of state of the cell wall peptidoglycan. At around $47^{\circ} \mathrm{C}$ the first irreversible denaturation events occur, associated with melting of the $30 \mathrm{~S}$ ribosomal subunit and denaturation of some of the soluble cytoplasmic proteins. Ribosome melting takes place over a broad temperature range between 47 and $85^{\circ} \mathrm{C}$ and is characterized by three peaks denoted $m_{1}$, $m_{2}$ and $n$. The process is complex and involves the sequential but overlapping denaturation of $30 \mathrm{~S}, 50 \mathrm{~S}$ and $70 \mathrm{~S}$ particles, denaturation and/or loss of ribosomal protein, loss of higher-order structure, and melting of helical regions of the rRNA. A peak denoted $m_{3}$ at 75$76{ }^{\circ} \mathrm{C}$ is seen in whole cells but not in pure $70 \mathrm{~S}$ ribosomes. The source of this is unknown but may be associated with melting of tRNA. At around $95^{\circ} \mathrm{C}$, peak $p$ occurs, resulting from the melting of a portion of the cellular DNA combined with denaturation of a component of the cell wall. Peak $q$ at approximately $105^{\circ} \mathrm{C}$ in whole cells, is also multicomponent and may also be caused by melting of regions of DNA together with denaturation of a cell wall component.

The complex events denoted $r / s$ with peaks at 118 and $125^{\circ} \mathrm{C}$ may be caused by denaturation of thermostable envelope-associated proteins and possibly also by nucleic acid.

Following cooling and reheating there is a peak $f_{\mathrm{r}}$ in the low temperature region corresponding to the remelting of membrane lipid. This is followed by a broad endotherm extending from approximately 40 to $100^{\circ} \mathrm{C}$ with a maximum around $73^{\circ} \mathrm{C}$. This is caused by the reversible melting of ribosomal RNA. At $94^{\circ} \mathrm{C}$ in E. coli is peak $p_{\mathrm{r}}$ caused by melting of reannealed DNA. We have suggested previously that the temperature of this peak may be used to predict the $G+C$ content of bacterial DNA (Mackey et al., 1988). The peptidoglycan also yielded an exothermic process on reheating but this was not discernible in the whole cells.

In other work (Miles et al., 1986; Mackey et al., 1988), involving examination of the thermograms of 63 other species of vegetative cells, we found that it was generally, but not always, possible to recognize peaks corresponding to those labelled $m, n, p, p_{\mathrm{r}}$ and $q$ in $E$. coli (and we now add $f$ and $f_{\mathrm{r}}$ to that list). Therefore, the identifications made here of components of $E$. coli allow at least tentative identification of some peaks in other species. 
The work also provides the information required for studying the effects of varying external or internal, and chemical or physical environments on the heat stability of particular cellular components by calorimetric measurements of whole cells and may furnish the means for estimation of their concentration in cells at different stages of growth, or growth under different conditions. Differential scanning calorimetry produces a diagram of the major thermal events underlying the response of micro-organisms to heat, and by identifying thermogram features we are providing points of reference which may be compared with the cardinal temperatures to provide insight into the causes of heat inactivation of bacteria.

We thank M. Calcutt for advice on the preparation of ribosomes.

\section{References}

Barritault, D., Guerin, M. F. \& Hayes, D. H. (1979). Reconstitution of active 30-S ribosomal subunits in vitro using heat-denatured 16-S rRNA. European Journal of Biochemistry 98, 567-571.

Dougan, G. \& SherRatT, D. (1977). The transposon Tnl as a probe for studying ColEl structure and function. Molecular and General Genetics 151, 151-160.

GoNDA, K. \& KOGA, S. (1973). Low temperature thermograms of Saccharomyces cerevisiae. Journal of General and Applied Microbiology 19, 393-396.

Gould, G. W. (1989). Heat-induced injury and inactivation. In Mechanisms of Action of Food Preservation Procedures, pp. 11-42. Edited by G. W. Gould. London: Elsevier Applied Science.

Halverson, C. A., Esser, A. F. \& SouzA, K. A. (1978). Temperaturedependent morphological changes in membranes of Bacillus stearothermophilus. Journal of Supramolecular Structure 8, 129-138.

HANCOCK, I. \& Poxton, I. (1988). Bacterial Cell Surface Techniques. Chichester: John Wiley \& Sons.

Herbert, D., Phipps, P. J. \& Strange, R. E. (1971). Chemical analysis of microbial cells. Methods in Microbiology 5B, 209-344.

JACKSON, M. B. \& CronAN, J. S. (1978). An estimate of the minimum amount of fluid lipid required for the growth of Escherichia coli. Biochimica et Biophysica Acta 512, 472-479.

LEON, S. A. \& BROCK, T. D. (1967). Effect of streptomycin and neomycin on physical properties of ribosomes. Journal of Molecular Biology 24, 391-404.

Mackey, B. M., Parsons, S. E., Miles, C. A. \& Owen, R. J. (1988). The relationship between the base composition of bacterial DNA and its intracellular melting temperature as determined by differential scanning calorimetry. Journal of General Microbiology 134, 11851195.

Maeda, Y., Noguchi, S. \& Koga, S. (1974). Differential scanning calorimetric study of spontaneous germination of Bacillus megaterium spores by water vapour. Journal of General and Appplied Microbiology 20, 11-19.

MARR, A. G. \& InGraham, J. L. (1962). Effect of temperature on the composition of fatty acids in Escherichia coli. Journal of Bacteriology 84, $1260-1267$.
McElhaney, R. N. (1982). The use of differential scanning calorimetry and differential thermal analysis in studies of model and biological membranes. Chemistry and Physics of Lipids 30, 229-259.

MCElHaneY, R. N. (1986). Differential scanning calorimetric studies of lipid-protein interactions in model membrane systems. Biochimica et Biophysica Acta 864, 361-421.

MeLCHIOR, D. L. \& SteIM, J. M. (1976). Thermotropic transitions in biomembranes. Annual Review of Biophysics and Bioengineering 5, 205-238.

Miles, C. A., Mackey, B. M. \& Parsons, S. E. (1986). Differential scanning calorimetry of bacteria. Journal of General Microbiology 132, 939-952.

Miller, J. H. (1972). Experiments in Molecular Genetics. Cold Spring Harbor, NY: Cold Spring Harbor Laboratory.

NeIDHARDT, F. C. (1987). Chemical composition of Escherichia coli. In Escherichia coli and Salmonella typhimurium, Cellular and Molecular Biology, vol. I, pp. 3-6. Edited by J. C. Ingraham, K. Brooks Low, B. Magasanik, M. Schaechter \& H. E. Umbarger. Washington, DC: American Society for Microbiology.

Noller, H. F. \& NOMURA, M. (1987). Ribosomes. In Escherichia coli and Salmonella typhimurium, Cellular and Molecular Biology, vol. I, pp. 104-125. Edited by J. C. Ingraham, K. Brooks Low, B. Magasanik, M. Schaechter \& H. E. Umbarger. Washington, DC: American Society for Microbiology.

Pellon, J. R. \& Sinskey, A. J. (1984). Heat induced damage to the bacterial chromosome and its repair. In The Revival of Injured Microbes (Society for Applied Bacteriology Symposium Series no. 12), pp. 105-125. Edited by M. H. E. Andrew \& A. D. Russell. London: Academic Press.

SCHLESSINGER, D. (1960). Hypochromicity in ribosomes from Escherichia coli. Journal of Molecular Biology 2, 92-95.

SteIM, J. M. (1972). Membrane transitions: some aspects of structure and function. In Mitochondria and Biomembranes, pp. 185-196. Edited by S. A. Van der Berg and others. Amsterdam: North Holland.

TAL, M. (1969). Thermal denaturation of ribosomes. Biochemistry 8 , 424-435.

TAMAOKI, T. \& MiYazawa, F. (1966). Dissociation of ribosomes at high temperatures. Journal of Molecular Biology 17, 537-540.

TOMLINS, R. I. \& ORDAL, Z. J. (1976). Thermal injury and inactivation in vegetative bacteria. In Inhibition and Inactivation of Vegetative Microbes (Society for Applied Bacteriology, Symposium Series no. 5), pp. 153-190. Edited by F. A. Skinner \& W. B. Hugo. London: Academic Press.

VAN Holde, K. E. \& Hill, W. E. (1974). General physical properties of ribosomes. In Ribosomes, pp. 53-91. Edited by M. Nomura, A. Tissieres \& P. Lengyel. Cold Spring Harbor, NY: Cold Spring Harbor Laboratory.

Verbeke, M. N., Van Cauwelaert, F. H. \& Jadot, R. (1981). Calorimetric aspects of spores of Phycomyces blakesleeanus. Biochemical and Biophysical Research Communications 98, 915-921.

VERRIPS, T. \& BREVOORT, H. (1979). Some molecular aspects of the heat inactivation of $C$. freundii. Antonie van Leeuwenhoek 45, 613 .

VERRIPS, C. T. \& KWAST, R. H. (1977). Heat resistance of Citrobacter freundii in media with various water activities. European Journal of Applied Microbiology 4, 225-231.

WOLFE, A. D. \& HAHN, F. E. (1968). Stability of ribosomes from streptomycin-exposed Escherichia coli. Biochemical and Biophysical Research Communications 31, 945-949. 